\title{
Group Interaction as the Crucible of Social Identity Formation: A Glimpse at the Foundations of Social Identities for Collective Action
}

\author{
Emma F Thomas ${ }^{1}$ \\ Craig McGarty ${ }^{2}$ \\ Ken Mavor $^{3}$ \\ ${ }^{1}$ Murdoch University \\ ${ }^{2}$ The University of Western Sydney \\ ${ }^{3}$ The University of St Andrews
}

Accepted Group Processes and Intergroup Relations 17 August 2015

5823 words

Correspondence regarding this manuscript should be sent to: Emma F. Thomas, School of Psychology \& Exercise Science, Murdoch University, Perth, WA, 6150, Australia. E-mail: emma.thomas@murdoch.edu.au. This research was supported by the Australian Research Council (DE120101029 to the first author and DP0770731 to the second author). 
THE FOUNDATIONS OF IDENTITY AND ACTION

\begin{abstract}
Many of the world's biggest problems are being tackled through the formation of new groups yet very little research has directly observed the processes by which new groups form to respond to social problems. The current paper draws on seminal research by Lewin (1947) to advance a perspective as to how such identities form through processes of small group interaction. Multi-level structural equation modelling involving 58 small group discussions (with $N=234$ ) demonstrates that focused group discussion can boost the commitment to take collective action, beliefs in the efficacy of that action and members' social identification with other supporters of the cause. The results are consistent with the new commitment to action flowing from emergent social identities.
\end{abstract}

Keywords: Social identity formation, small group interaction, collective action. 
THE FOUNDATIONS OF IDENTITY AND ACTION

\section{Group Interaction as the Crucible of Social Identity Formation: A Glimpse at the Foundations of Social Identities for Collective Action}

In order to effect large scale social change we clearly need to do more than focus individual minds on the future. Instead, we need large sections of the public to embrace sustainable solutions collectively. To promote collective action of this kind, we need to fuse individual orientations toward the future with social identities that have the capacity to engender and sustain positive action. (Postmes, Rabinovich, Morton, \& van Zomeren, 2012, p.194)

The field of social psychology is filled with research on attitude change, prejudice, self-concept formation, stereotyping, and emotions, most of which has ignored how these processes operate in small groups. This neglect means that many questions central to the human social experience have not been investigated. (Wittenbaum \& Moreland, 2008, p.188)

In 1947 Kurt Lewin, one of the founders of modern social psychology, published findings of research into what he termed 'group decision'. Charged with the task of finding ways to change attitudes towards serving offal as a family meal as part of the World War II effort, Lewin compared the effects of listening to a lecture, with the effects of group discussion on samples of women who made food purchasing decisions for their families. The findings were striking. Of the women who had listened to the lecture, only $3 \%$ went on to prepare offal. Conversely, of those who had participated in a group discussion (about difficulties facing women in serving offal), $32 \%$ subsequently served offal to their families. Lewin (1958, p.202) concluded that "discussion, if conducted correctly, is likely to lead to a much higher degree of involvement”. 
The legacies of this study were twofold. Lewin was the first to demonstrate the powerful effects of group interaction on changing attitudes and behaviour, findings that were mirrored some years later with the advent of the group polarization phenomenon (Moscovici \& Zavalloni, 1969; Myers \& Bishop, 1970). Lewin (1947, p. 150) was also the founder of action research, declaring "research that produces nothing but books will not suffice". This point is mirrored in contemporary psychological debate where there is an emerging consensus that (social) psychology can and should do more to tackle issues of global importance (e.g. human induced climate change, global poverty; see, e.g. Bazerman \& Malhotra, 2006; Leidner, Tropp \& Lickel, 2013).

The current research draws on the two prongs of the Lewinian legacy by extending an analysis of group interaction as it relates to social identity formation and collective action. We suggest that an important part of social psychology's ability to contribute solutions to contemporary global problems hinges on its ability to explain the origins or foundations of psychological group formation. This is because many of the most significant problems that confront us today are problems that require collective solutions (e.g. Postmes, Rabinovich, Morton, \& van Zomeren, 2010 above; Jonas \& Morton, 2012; Louis, 2009). Intriguingly, Lewin's two legacies - group decision through social interaction and action research - may, in combination, provide some significant insights as to how to generate collective identities that promote sustainable action. The current analysis explores this possibility by drawing on recent developments in the social psychology of social identity formation (Postmes, Haslam, \& Swaab, 2005) and collective action (Thomas, McGarty, \& Mavor, 2009; Thomas, Mavor, \& McGarty, 2012; van Zomeren, Postmes, \& Spears, 2008) to specify the role of group interaction in promoting the development of new social identities that are built for action. 
THE FOUNDATIONS OF IDENTITY AND ACTION

\section{Group Interaction and Social Identity Formation}

Despite widespread recognition of the importance of Lewin's results, research involving group interaction has been relatively rare in social psychology in the intervening decades. Several reviews of the trends in research in social psychology have documented marked declines in studies involving social interaction (Haslam \& McGarty, 2001; Moreland, Hogg, \& Hains, 1994; Wittenbaum \& Moreland, 2008). Haslam and McGarty (2001) account for this trend as evidence of a focus on uncertainty reduction (and concomitant low tolerance for statistically and methodologically 'messy' data) at the cost of a truly interactionist social psychology (Turner \& Oakes, 1986; see also Wittenbaum \& Moreland, 2008). It is also the case that research on intragroup processes and intergroup relations have tended to occupy separate conceptual and empirical trajectories (see Dovidio, 2013, for a review; Hogg, Abrams, Otten \& Hinkle, 2004). Whereas the small group literature has focused on group performance, cohesion and performance (e.g. Levine \& Moreland, 2002), the intergroup relations literature has tended to focus on social identity, conflict, and competition (Dovidio, 2013). The dearth of research into social interaction within the intergroup domain has arguably left some of Lewin's most important insights to wither on the vine. Indeed, one recent review identifies group discussion as one of the most significant drivers of cooperative behaviour but notes a considerable lack of insight as to why this is the case (Meleady, Hopthrow, \& Crisp, 2012; see also Hopthrow \& Abrams, 2010). Postmes, Spears, Lee, and Novak (2005) identify a similar lack of theoretical resolution in relation to the group polarization phenomenon.

A small number of recent papers have, however, made progress in identifying the mechanisms that underpin the effects of small group interaction as they relate to social identity formation, social influence and social action (Abrams, Wetherell, Cochrane, Hogg \& 
Turner, 1990). An important contribution in this regard is Postmes et al.'s (2005; also Postmes, Spears, et al., 2005) interactive model of identity formation, where it is argued that inductive social identity formation occurs through small group interaction. Inductive identities form through communication, consensualization and negotiation about what it means to be a group member and can stem from recognition of shared cognitions (thoughts and beliefs) amongst people (Swaab, Postmes, van Beest, \& Spears, 2007) or from a discussion of individual differences (Jans, Postmes, \& van der Zee, 2011). Consistent with this account, social interaction has been implicated in the expression of intergroup hostility (Smith \& Postmes, 2009; Smith \& Postmes, 2011a). Other research shows that group interaction is central to the validation of social stereotypes (Haslam et al., 1998; Stott \& Drury, 2004), and can act to politicize and (under particular circumstances) radicalize sympathizers (Thomas, McGarty, \& Louis, 2014). Elsewhere, Smith and Postmes (2011b) showed that group discussion about a negative social stereotype ("women are bad at maths") acted as a buffer against stereotype threat.

In an important extension of this argument, McGarty, Bliuc, Thomas, and Bongiorno (2009) have proposed that small group interaction provides a vehicle for the intensification of opinion-based group memberships (groups based on shared opinions; Bliuc, McGarty, Reynolds, \& Muntele, 2007). That is, targeted small group discussion provides a site where people can negotiate and validate a position about 'how we want the world to be' (Gee, Khalaf, \& McGarty, 2007; Thomas \& McGarty, 2009). Intensifying opinion-based group memberships specifically (rather than other broader social identities that can be contested; Sani \& Reicher, 2000) seems particularly important since these identities can be implicitly aspirational or future-oriented (Rabinovich, Morton \& Postmes, 2010); they are geared towards establishing (or preventing) a particular state of affairs (see Smith, Thomas \& McGarty, in press). If our goal is to develop identities that engender action in the present but 
are sustainable into the future then opinion-based groups may be fruitful candidates (see Thomas et al., 2009, for a detailed consideration of this point). Consistent with these arguments, Thomas and McGarty (2009) found that group interaction boosted social identification with an anti-poverty opinion based group and increased commitment to act in line with global poverty reduction efforts.

It also seems plausible that forming a novel identity through small group interaction will affect some components of social identification more than others. Social identification is a multi-dimensional construct (see Ashmore, Deaux, \& McLaughlin-Volpe, 2004, for a review) where these identity dimensions may relate to connection, satisfaction and selfdefinition (Cameron, 2004; Leach et al., 2008). In the context of the current research, it might take time (weeks, months, or years) for a group membership to become central to selfperception. It might take the experience of actual collective success or failure to influence group affect (e. g., Tausch \& Becker, 2013). On the other hand, during the early stages of group formation, a bolstered sense of connectedness to, or solidarity with, other group members should arise from interaction (e. g., Jans et al., 2011). Accordingly, the current paper treats social identification as a multidimensional construct and explores the role of the different identity components in the early stages of psychological group formation.

\section{Collective Action for Social Change}

Social psychology has also made recent progress in addressing another question close to Lewin's heart: how to motivate action for social change. The social identity model of collective action (SIMCA: van Zomeren et al., 2008) suggests that people will engage in group-level efforts to bring about, or subvert, social change when they believe that coordinated group efforts can be successful (group efficacy; Bandura, 1997, 2000), experience motivating emotional reactions to the injustice (anger or outrage; see Thomas, Mavor \& 
McGarty, 2012; Thomas, McGarty, Stuart, Lala, Hall \& Goddard, 2015), and identify with relevant groups that can mobilise action (social identity; following Reicher, 1984, 1996). Indeed, van Zomeren and colleagues (2008) posit a particularly important role for the social identity pathway, whereby social identification has direct effects on collective action, as well as indirect effects on action through relevant reactions to injustice (e.g. anger or outrage) and beliefs (group efficacy).

More recently still, Thomas et al. $(2009,2012)$ proposed the encapsulation model of social identity in collective action (EMSICA). EMSICA anticipates the same pathways as SIMCA (injustice, efficacy and identity) but proposes that new identities can emerge out of shared reactions (injustice and efficacy) to a state of affairs. Thomas et al., (2009, p. 206) argued that: "in everyday social interaction we might expect that in some situations it will be the strong affective reactions and feelings of efficacy that precede group formation”. Accordingly, EMSICA anticipates direct effects of social identification on collective action but social identification also captures (and attenuates) the indirect effects of reactions to injustice (anger or outrage) and efficacy. Put differently, the subjective feelings and beliefs associated with group membership become bound up in the social identity, rendering the direct links less important (Thomas et al., 2012; Thomas et al., in press).

Whereas SIMCA may be more relevant to identities that already exist (e. g., national, gender or ethnic categories), EMSICA seems particularly relevant to understanding the interactive formation of emerging social identities that grow around the need to take action. This is because social identity formation is premised in knowledge about similar others' views and judgements (e.g. Swaab et al., 2008). That is, it is difficult for people to form groups based on opinions about how the world should be without knowing what other people's opinions are (Hardin \& Higgins, 1996). If this is the case it seems likely that 
discussions that allow people to express support for a cause and plan ways to achieve it should contribute to the foundation for identity formation rather than be supplementary to it (see also van Zomeren et al., 2004). We therefore expect that the encapsulated model of collective action will be highly applicable to inductively forming identities in interacting groups.

\section{The Current Research}

The current research involves a structural analysis of the outcomes of 58 small group discussions. Existing research identifies group interaction as a vehicle for social identity formation (Postmes et al., 2005) and opinion-based group identification in particular (Thomas \& McGarty, 2009). The collective action literature, on the other hand, articulates a prominent role for social identification in promoting collective action (van Zomeren et al., 2008). This research integrates recent advances in social identity formation and collective action to describe the formation of action-oriented social identities. In doing so, it answers recent calls to explicitly bridge research on intergroup relations (collective action) with intragroup processes (small group interaction; see Dovidio, 2013). More specifically, the current research goes beyond the existing literature in three key ways.

First, we use multi-level structural equation modelling to test the relative applicability of EMSICA and SIMCA in the context of small groups engaged in social interaction. As anticipated above, we expect that EMSICA will better fit the data than SIMCA because it is more readily applicable to new, interactively forming groups. Second, we test social identification as a multidimensional construct in social identity formation. To date, the multidimensionality of identity has been under-explored in relation to the effects of group interaction and collective action more generally (see Cameron \& Nickerson, 2009; Giguere \& Lalonde, 2010, for exceptions). However, recent developments in the intergroup literature 
increasingly recognise that different aspects of identification can promote distinct (positive and negative) forms of intergroup behaviour (e.g. Amiot \& Aubin, 2013; Roccas, Klar \& Liviatan, 2008). Accordingly, the current research considers social identification at the component level to explore whether group interaction exerts effects on all dimensions of identification. Finally, while our core aim is to test the applicability of SIMCA and EMSICA within interacting groups, we also seek to establish whether group interaction affects identification, outrage, efficacy and commitment to action compared to a relevant (noninteraction) control.

\section{Method}

\section{Participants}

Participants across three samples $(N=120 ; N=103 ; N=186$ respectively) were primarily first year psychology students at an Australian university who participated for course credit or people recruited on campus in exchange for $\mathrm{A} \$ 10$. Altogether 409 people participated, of whom 256 were female and 126 were male; there was no gender recorded for 27 participants. Participants' median age was between 18 and 25; $90 \%$ of people for whom age was recorded fell into this category.

\section{Procedure}

The procedure was similar across the three different samples and the core factor is whether participants engaged in interaction, or not (see also Thomas \& McGarty, 2009). All subjects read an information sheet about the state of waterborne disease in developing nations, the role of governments, and the 'Water for Life' movement (a United Nations movement which seeks to achieve clean water for people in developing countries). At the end of this information participants were asked to tick a box indicating whether they supported (or did not support) the 'Water for Life' movement. All participants indicated their support. 
Participants were then given the information that, the [University] was interested in the 'Water for Life' campaign, and that their task was to come up with strategies to help promote the 'Water for Life' message. ${ }^{1}$ All participants were given the written information that their strategies would be written up and sent to various advocacy groups, and posted on a website linked to [the University]. Participants were provided with a sheet of paper upon which to write their recommendations. Participants in the group interaction conditions were formed into small groups of three to five people and were left to engage in the group discussion for half an hour. At the end of this period all participants completed a questionnaire. Participants assigned to a control condition completed the questionnaire without group interaction (i.e. immediately after reading the information about the 'Water for Life' program; Study 1) or completed a comparable brainstorming task individually without group interaction (Studies 2 and 3).

\section{Questionnaire}

Across all studies the questionnaire was titled 'Attitudes towards support for people in developing nations'. Measures were taken of social identification, outrage, group efficacy, and collective action intention. Below we detail the measurement strategy for each construct. All items were measured on an eleven-point Likert-type scale anchored 1 ('Strongly disagree') to 11 ('Strongly agree') and were internally consistent.

Social identification. Identification with the pro-'Water for Life' group was measured using Cameron's (2004) three-factor measure of social identification. Examples of these measures are: 'Being a supporter of programs such as 'Water for Life' is an important reflection of who I am' (centrality); 'I have a lot in common with other supporters of programs such as 'Water for Life', (ingroup ties); 'In general, I'm glad to be a supporter of programs such as 'Water for Life"' (ingroup affect). The three sub-components were 
internally consistent: centrality $(\alpha=.65-.79)$, ingroup ties $(\alpha=.65-.85)$ and ingroup affect $(\alpha$ $=.52-.76)$.

Outrage. Participants responded to four items which read: 'Thinking about the situation of people in developing countries, I feel angry / irritated / outraged / livid'. Responses to these adjectives were aggregated to form a scale $(\alpha=.84-.90)$.

Group efficacy. Group efficacy was measured with three items adapted from van Zomeren et al. (2004): 'I feel that together the 'Water for Life' program will be able to improve the water situation in developing nations', 'The 'Water for Life' campaign will be a waste of time, effort and money' (reverse scored); and 'The 'Water for Life' campaign will be successful in its aims to provide safe and clean drinking water for those in developing countries'. These were combined to form a scale $(\alpha=.74-.89)$.

Collective action intentions. Commitment to undertake action to reduce the disadvantage of people in developing countries was measured by a series of items designed to represent an escalating degree of commitment to the cause. An example is: 'I intend to support the 'Water for Life' movement by attending a rally which calls for greater government support for the initiative.' Other items were similarly worded and regarded signing a petition, donating money, talking to others, attending a rally, writing a letter to a Member of Parliament, joining an advocacy group, and attending and organizing a 'Water for Life' fundraising event $(\alpha=.87-.91)$.

\section{Results}

\section{Intensification of Identity and Action Through Interaction}

Our main focus is on the processes underlying commitment to change but it is also important to establish whether group interaction itself produced increased identification, 
emotion, efficacy beliefs and commitment. The key data involve observations that are nonindependent (due to group interaction) but we also had control condition observations where people completed the same measures without group interaction. In order to make the comparison between those who had interacted versus those who had not we analysed the group data but used the control (collected at the same time from participants randomly allocated to the control condition) to establish a baseline for each study. To prepare the group-level data, we first subtracted the control group mean for that sample from each interacting group mean. The subtraction of the control group mean simply allows us to test the mean level in the interacting groups with the mean level in the control condition (analogous to using a t-test to compare a mean to a scale midpoint). This strategy yields a deviation score expressing the strength of the effect in that group, relative to our best point estimate of the population level of the variable in the absence of group interaction (and taking account of random variation across studies). There were $N=58$ groups based on 234 responses. As the data were also clustered at the study level (i. e., they are comprised of three samples collected at different points in time) all the analyses below also control for the effect of study.

Table 1 shows the means and standard deviations for the group and control condition for each of the three samples, as well as the pooled mean. Table 1 also displays a $95 \%$ confidence interval for the deviation from the control condition is shown around the pooled mean (obtained by using the test of the intercept in the null model). In the absence of a direct multilevel equivalent of between groups ANOVA this allows comparisons of effects between the three samples but without inflating the Type 1 error rate by making multiple (post hoc) pairwise comparisons. As would be expected from repeated sampling of effects of small to moderate size with moderate sample sizes there is some variability in the significance levels 
of effects across studies. It suggests that the strongest effects were in Study 1 and weak or no effects in Study 3.

Analysis using MPlus to control for nonindependence of observations revealed that the mean levels differed from the control means for action intentions, efficacy, and the ties and centrality components of identification, but not for the affective component of identification or outrage (though the negative effect was marginal). This demonstrates that group interaction produced an intensified commitment to action intentions and bolstered two of the hypothesized drivers of action (efficacy, and two of the three components of social identification).

\section{EMSICA and SIMCA Models}

Our next analyses utilized the deviation scores to test the relationships amongst variables. Our goal was to compare the two theoretical models of identity and collective action in predicting variation in support for collective action amongst participants in the interacting groups. By using the deviation scores we can focus our attention on the effects in the interacting groups only and control for sample differences by anchoring them relative to the non-interaction controls in each study. Correlations between variables across the three samples are displayed in Table 2. To test our core hypotheses we conducted path analysis using MPlus. The path model was specified at the between-person level of analysis but was 'empty' at the between-group and study levels of analysis. Since the model considered only between-person relationships the SRMR(within) is the most relevant index to judge fit as other traditionally reported indices (CFI, RMSEA) are not reliable for multi-level models (Muthén \& Muthén, 2007). A value of zero indicates perfect fit for SRMR(within) and a value of less than .08 is generally considered good fit (Hu \& Bentler, 1999). 
We first tested the EMSICA model whereby social identification is a direct predictor of collective action and fully mediates (encapsulates) the effects of outrage and efficacy on action. This model fitted the data well (SRMR within $=.06)$. Figure 1 displays the standardized regression coefficients $(\gamma)$ for the multi-level model. It can be seen that all the paths were significant at $p<.001$. Tests of the indirect effects of efficacy on action through identification $(I E=.57, S E=.04, p<.001)$, and outrage on action through identification $(I E$ $=.25, S E=.05, p<.001)$, were both significant.

We next tested SIMCA. The model included social identification, outrage and efficacy as direct predictors of collective action; there were also direct links from identification to outrage and identification to efficacy to capture the facilitating effect of identification (and the potential mediated effect of identification through these variables). This model also fitted the data well $($ SRMRwithin $=.057)$; the standardized regression coefficients $(\gamma)$ are displayed in Figure 2. It can be seen that there were large effects of social identification on outrage, efficacy and action; however, the indirect effects of identification on action through outrage and efficacy were small and non-significant $(p s>.17)$. Given the non-significance of the direct paths between outrage-action and efficacy-action, the model implies that correlations between efficacy/outrage and action intentions are subsumed within their shared variance with social identification. This is consistent with the idea that social identity encapsulates the effects of efficacy and outrage. Altogether, the results support the idea that social identification is playing an encapsulation role rather than a facilitating role in the interactive formation of social identities.

\section{Components of Social Identification}

There are two important results pertaining to the identity components: intensification of the components due to interaction; and implications for the strength of the components in 
the mediation relationship. Table 1 shows that social interaction intensified commitment to ingroup ties (a psychological sense of connection to group membership) and centrality (centrality of the group membership to self-definition), while ingroup affect (feelings of satisfaction associated with group membership) was not bolstered in these data. Given that affect may nevertheless play a predictive role (even if it was not boosted at the mean level) we utilised a latent model with all three components in the tests of SIMCA and EMSICA. ${ }^{2}$ Figures 1 and 2 show that a latent factor representation of identification fitted well, though the non-significant loading suggests that the shared aspects of centrality and ties that predict action are not shared with affect.

\section{Discussion}

The current research sought to develop an analysis of the interactive origins of social identity in collective action. Multi-group structural equation modelling involving 58 group discussions showed that participating in a small group interaction bolsters two of the three dimensions of social identification (ties and centrality but not affect) and also perceived efficacy and collective action intentions but not outrage. Moreover, in line with the encapsulated model of social identity in collective action, the subjective feelings of being connected to, and belonging in, a group, acted as the conceptual and psychological link between group-based action-relevant emotions (outrage), beliefs (group efficacy beliefs) and actions (collective action intentions). The causal ordering anticipated by the social identity model of collective action also fit these data well, however the absence of significant paths between outrage and action, and efficacy and action, suggests that identification is playing an encapsulation role in these data. In other words, it seems that outrage and efficacy overlap with social identification and that identification is effectively capturing the variability associated with those reactions. Whereas SIMCA may be more relevant to identities that already hold subjective meaning for participants (e. g., social categories such as race, gender; 
membership of social movement organizations; see van Zomeren et al., 2008 meta-analysis), the encapsulating function of identity anticipated by EMSICA may be more readily applicable to new, interactively formed groups. In what follows we consider the implications of current findings for the literatures on group interaction and collective action more generally.

\section{Social Interaction, Social Identity Formation and Sustainable Collective Action}

Lewin's famous group decision study established the important effect of informal group discussion. However, subsequent declines in the experimental study of social interaction and the separate trajectories of research on intragroup and intergroup processes ensured that the potential for group interaction to shed light on intergroup phenomena like collective action has remained relatively untapped. Haslam and McGarty (2001; also Wittenbaum \& Moreland, 2008) note that one of the most significant casualties of the decline in research that involves group interaction is that it limits the study of consensus, a topic that should be of central concern to social psychologists. This seems particularly true of collective action, where group-based efforts to address inequality are central; knowing what relevant others think and intend to do seems fundamental to group formation (Klandermans, 1997; van Zomeren et al., 2004).

Indeed, the little available research on small group interaction in intergroup contexts highlights that people, tested in isolation (compared to in interacting groups), will come to often markedly different conclusions about social behaviour (Haslam et al., 1998; Stott \& Drury, 2004; Smith \& Postmes, 2009, 2011a, b; Smith et al., in press; Thomas \& McGarty, 2009; Thomas et al., 2014). It is reassuring, then, that the current research supports the causal pattern of inter-relations suggested by SIMCA and EMSICA (models both derived in the absence of interaction; see Thomas et al., 2012, for a test of both models). We suggest that 
there is a distinction to be made here between structural models, those models that describe a set of predictors or correlates (in this case, with collective action); and transformational models, those that describe the processes and mechanisms associated with change (in this case, the processes through which identities are formed and transformed). This is akin to the distinction between social identity as a fixed construct; and social identification as a process (Drury \& Reicher, 2000, 2005). The current research sits between these two extremes by identifying the dynamic and interactive ways in which people construe their sense of self through social interaction.

Moreover, the current research explores the specific dimensions of social identity that are most relevant to social identity formation through interaction. We found that group interaction effectively bolstered two of the three dimensions of identification (effects on ingroup ties and centrality were greater than those for ingroup affect) but that a single factor solution nevertheless fitted the data well. However, consistent with arguments by Jans et al. (2011, p.1133) who suggested that a sense of connection to the group speaks to a more "organic process" of inductive identity formation, it seems that developing a sense of psychological connection with group members (ingroup ties) may play a more prominent role in capturing effects in the early stages of group formation. This is not surprising as the ingroup ties component (in the Leach et al., 2008, typology named 'solidarity') may be especially easy to bolster in small group interactions between strangers and this factor may therefore be an especially good platform for action.

Finally, it is worth considering one alternative construal of these findings: that the results show nothing more than group polarization (that is, the tendency for group discussion to polarize attitudes in the direction in which they were already tending; Moscovici \& Zavalloni, 1969). We agree that the processes in operation here are closely related to what 
has been termed group polarization. However, it is also the case that group polarization is a more complex and sophisticated phenomenon than it is commonly understood to be.

Notwithstanding the conclusions of Isenberg (1985), there remains significant uncertainty about what produces the effects of group discussion on attitude polarization (Postmes et al., 2005) and cooperation more generally (Meleady et al., 2012). Indeed, the current data go well beyond existing accounts of polarization by offering a substantiated account of process in terms of the development of identity (Postmes et al., 2005; Thomas et al., 2009) and demonstrate effects not only on the matters under discussion (as in standard group polarization studies) but on a subset of other measures that were not discussed by the groups (including ones sense of self).

\section{Limitations and Future Directions}

One avenue for future research regards the (marginal) negative effect of outrage in the group interaction conditions: that is, while outrage was a strong qualitative predictor of identity, beliefs and commitment to action (Table 2), group interaction may reduce felt outrage at the mean level (Table 1). Why might group discussion attenuate feelings of outrage? One possibility is that, having engaged in the interactive planning session, participants feel as though they have acted and this feeling of action assuages the emotional reaction (as in, e.g. Stürmer \& Simon, 2009). Another possibility is that, as group members engage with the problems confronting people in developing countries, their emotions transition from 'raw' experiences of anger, to more situated 'normative' expressions of emotion (see Thomas et al., 2009); such a pattern is reportedly typical of long-term activists (e.g. Groves, 1995). Future research could test the reliability of this effect and consider these possibilities. 
A further avenue for research concerns the multi-dimensional nature of identification. Although we have modelled identification as a latent factor, the finding that affect was not intensified by social interaction (and nor did it share the strong predictive relationship of centrality and ties) suggests that the mediating (encapsulating) role of the components may operate somewhat differently. Future research should consider the possibility that the different dimensions of identity may play a different role at distinct stages of the identity formation process. Indeed, recent research has demonstrated that social identity components have different effects on discrete parts of intergroup phenomena (cooperation v competition; Amiot \& Aubin, 2013). Accordingly, future research might consider the role of the subcomponents in affecting collective actions, emotions and beliefs, and at discrete stages of the "commitment trajectory" (that is, in contexts where people first become aware of a group, develop and sustain their commitment.)

It is also possible that identification encapsulates efficacy and outrage simply because the meaning of the group (and the broader social movement) is ill-defined for participants. If this is the case, then it may be that some of the paths observed here are more unstable at other time points (e.g. as participants become more familiar with normative expectations for supporters). It is also unclear whether the specific pattern of findings observed here will generalize to other issues: Are opinion-based identities distinguishable from a broader ideological orientation (see, e.g. Bliuc et al., 2015)? Finally, exploring the content of the actual interactions is also a crucial avenue for future research: what is it specifically about the social communication within interacting groups that promotes identification and action?

More generally, Dovidio (2013) recently advocated for a renewed focus on research that understands the reciprocal relationship between intragroup processes and intergroup 
relations. Intragroup interaction is arguably the social psychological crucible of these effects and should be more routinely utilised in experimental social psychological research.

\section{Sustainable Collective Action}

The current research draws on seminal past (Lewin, 1947, 1953) and recent research to consider the processes through which people form collective efforts to redress social inequality. We argued at the beginning of this paper that social change is likely to be predicated on the formation of new groups that can promote action in the present but are sustainable into the future (Thomas et al., 2009; also Jones \& Morton, 2012; Rabinovich et al., 2010; Postmes et al., 2012). We also suggested that opinion-based group memberships are useful candidate groups in this regard (McGarty et al., 2009; McGarty, Lala \& Thomas, 2012). Consistent with these points, these results experimentally demonstrated that opinionbased groups can emerge through social interaction and effectively capture action-oriented reactions (outrage and efficacy) and boost commitment to a pressing global problem (combating global poverty). Put differently, through interaction group members generated a collective identities such that 'what it means' to be a supporter of an end to global poverty meant to experience those emotions (outrage), believe in the usefulness of action (efficacy) and to take that action; all elements of a normative alignment (Thomas et al., 2009).

These processes have a powerful analogy in everyday social interaction where, as Klandermans (1997, p. 211, emphasis added), argues "protest is staged by people who come to share a contentious identity". It is precisely that process of becoming that the current research has sought to specify (Reicher \& Hopkins, 2001; Haslam, Reicher \& Platow, 2011; Smith et al., in press). The results point to the practical importance of allowing people to come to a new understanding of self by harnessing the power of social interaction. 
THE FOUNDATIONS OF IDENTITY AND ACTION

\section{References}

Abrams, D., Wetherell, M., Cochrane, S., Hogg, M.A. \& Turner, J.C. (1990). Knowing what to think by knowing who you are: Self-categorization and the nature of norm formation, conformity and group polarization. British Journal of Social Psychology, 29, 97-119.

Amiot, C.E. \& Aubin, R.M. (2012). Why and how are you attached to your social group? Investigating different forms of social identification. British Journal of Social Psychology, 52, 563-586.

Aiken, L. \& West, S.G. (1991). Multiple Regression: Testing and Interpreting Interactions. Thousand Oaks, California: Sage.

Ashmore, K.D., Deaux, K., McLaughlin-Volpe, T. (2004) An organizing framework for collective identity: Articulation and significance of multi-dimensionality. Psychological Bulletin, 130, 80-113.

Bandura, A. (1997). Self-efficacy: The Exercise of Control. New York: W.H Freeman \& Co.

Bandura, A. (2000). Exercise of human agency through collective efficacy. Current Directions in Psychological Science, 75-78.

Bazerman, M.H, \& Malhotra, D. (2006). Economics wins, psychology loses, and society pays. In D. De Cremer, M. Zeelenberg \& J. K. Murnighan (Eds.), Social Psychology and Economics (pp. 263-297). New Jersey: Lawrence Erlbaum Associates.

Bliuc, A., McGarty, C., Reynolds, K. J., \& Muntele, D. (2007). Opinion-based group membership as a predictor of commitment to political action. European Journal of Social Psychology, 37, 19-32. 
Bliuc, A.-M, McGarty, C., Thomas, E.F., Lala, G., Berndsen, M., \& Misajon, R. (2015). Understanding the climate change divide as an intergroup conflict between skeptics and believers. Nature Climate Change, 5, 226-229. DOI:10.1038/nclimate2507

Cameron, J. (2004). A three-factor model of social identity. Self and Identity, 3, 239-262.

Cameron, J. \& Nickerson, S.L. (2009). Predictors of protest amongst anti-globalization protesters. Journal of Applied Social Psychology, 39, 734-761.

Dovidio, J. (2013). Bridging intragroup processes and intergroup relations: Needing the twain to meet. British Journal of Social Psychology, 52, 1-24.

Drury, J., \& Reicher, S. (1999). The intergroup dynamics of collective empowerment: Substantiating the social identity model of crowd behaviour. Group Processes and Intergroup Relations, 2(4), 381-402. DOI: 10.1177/1368430299024005

Drury, J., \& Reicher, S. (2000). Collective action and psychological change: The emergence of new social identities. British Journal of Social Psychology, 39, 579-604. DOI: $10.1348 / 014466600164642$

Ellemers, N., Kortekaas, P., Ouwerkerk, J. (1999). Self categorisation, commitment to the group, and group self-esteem as related but distinct constructs of social identity. European Journal of Social Psychology, 29, 371-389.

Gee, A., Khalaf, A., \& McGarty, C. (2007). Using group-based interaction to change stereotypes about people with mental disorders. Australian Psychologist, 42(2), 98 105. doi: 10.1080/00050060701280581

Giguere, B., \& Lalonde, R. (2010). Why do students strike? Direct and indirect determinants of collective action participation. Political Psychology, 31, 227-247. DOI: 10.1111/j.1467-9221.2009.00750.x 
Groves, J. M. (1995). Learning to feel: The neglected sociology of social movements. The Sociological Review, 43, 435-461. DOI: 10.1111/j.1467-954X.1995.tb00610.x

Hardin, C. D., \& Higgins, E. T. (1996). Shared reality: How social verification makes the subjective objective. In R. M. Sorrentino \& E. T. Higgins (Eds.), Handbook of motivation and cognition: The interpersonal context (Vol. 3, pp. 28-84). Mahwah, NJ: Erlbaum.

Haslam, S. A., \& McGarty, C. (2001). A 100 years of certitude? Social psychology, the experimental method and the management of scientific uncertainty. British Journal of Social Psychology, 40, 1-21.

Haslam, S. A., Reicher, S.D., \& Platow, M. J. (2011). The New Psychology of Leadership: Identity, Influence and Power. Hove, East Sussex: Psychology Press.

Haslam, S. A., Turner, J. C., Oakes, P. J., Reynolds, K. J., Eggins, R. A., Nolan, M., \& Tweedie, J. (1998). When do stereotypes become really consensual? Investigating the group-based dynamics of the consensualization process. European Journal of Social Psychology, 28(5), 755-776.

Hogg, M.A., Abrams, D., Otten, S. \& Hinkle, S. (2004). The social identity perspective: Intergroup relations, self-conception and small groups. Small Group Research, 35, 246-276.

Hopthrow, T. \& Abrams, D. (2010). Group transformation: How demonstrability promotes intra-group cooperation in social dilemmas. Journal of Experimental Social Psychology, 46, 799-803.

Jans, L., Postmes, T., van der Zee, K.I. (2011). The induction of shared identity: The positive role of individual distinctiveness for groups. Personality and Social Psychology Bulletin, 37, 1130-1141. 
Jonas, K. \& Morton, T.A. (2012 Eds.) Restoring civil societies: The psychology of intervention and engagement following crisis. Wiley-Blackwell: West Sussex, UK.

Klandermans, B. (1997). The Social Psychology of Protest. Oxford: Blackwell.

Leach, C. W., van Zomeren, M., Zebel, S., Vliek, M. L. W., Pennekamp, S., Doosje, B., Ouwerkerk, J. \& Spears, R. (2008). Group-level self definition and self-investment: A hierarchical (multicomponent) model of in-group identification. Journal of Personality and Social Psychology, 95, 144-165.

Leidner, B., Tropp, L., \& Lickel, B. (2013). Bringing science to bear - on peace, not war. Elaborating on psychology's potential to promote peace. American Psychologist, 68, 514-526.

Lewin, K. (1947). Frontiers in group dynamics II-Channels of group life; social planning and action research. Human Relations, 1(2), 143-153.

Lewin, K. (1958). Group decision and social change. In E. E. Maccoby, T. M. Newcomb \& E. L. Hartley (Eds.), Readings in Social Psychology (3rd ed., pp. 197-211). New York.

Louis, W.R (2009). Collective action - And then what? Journal of Social Issues, 65, 727-748.

McGarty, C., Bliuc, A.-M., Thomas, E.F., \& Bongiorno, R. (2009). Collective action as the material expression of opinion-based group membership. Journal of Social Issues, 65, 839-857. DOI: 10.1111/j.1540-4560.2009.01627.x

McGarty, C., Lala, G., Thomas, E.F, (2012). Opinion-based groups and the restoration of civil society. In K. Jonas \& T. Morton (Eds). Restoring Civil Society, WileyBlackwell: West Sussex, UK, pages 250 - 264. 
Moreland, R.L., Hogg, M.A., Hains, S.C. (1994). Back to the future: Social psychological research on small groups. Journal of Experimental Social Psychology, 30, 527-555.

Moscovici, S. \& Zavalloni, M. (1969) The group as a polarizer of attitudes. Journal of Personality and Social Psychology, 12, 125-135.

Muthén, L. K., \& Muthén, B.O. (2007). Mplus user’s guide. Seventh Edition. Los Angeles, CA: Muthén \& Muthén.

Myers, D.G \& Bishop, G.D (1970). Discussion effects on racial attitudes. Science, 169, 778779.

Obst, P. L. \& White, K.M (2005). Three-dimensional strength of identification across group memberships: A confirmatory factor analysis. Self and Identity, 4, 69-80.

DOI:10.1080/13576500444000182.

Obst, P. L., White, K.M, Mavor, K.I. \& Baker, R.M. (2011). Social identification dimensions as mediators of the effect of prototypicality on intergroup behaviours. Psychology, 2, 426-432. DOI:10.4236/psych.2011.25066.

Postmes, T., Haslam, S. A., \& Swaab, R. I. (2005). Social influence in small groups: An interactive model of identity formation. European Review of Social Psychology, 16, 142. DOI: $10.1080 / 10463280440000062$.

Postmes, T., Rabinovich, A., Morton, T.A., van Zomeren, M. (2012). Toward sustainable social identities: Including our collective future into the self-concept. In Van Trijp H (ed) Encouraging Sustainable Behavior, Psychology Press, 191-207.

Postmes, T., Spears, R., Lee, A. T., \& Novak, R. J. (2005). Individuality and social influence in groups: Inductive and deductive routes to group identity. Journal of Personality and Social Psychology, 89(5), 747-763. DOI: 10.1037/0022-3514.89.5.747 
Rabinovich, A., Morton, T., Postmes, T. (2010). Time perspective and attitude-behaviour consistency in future-oriented behaviours. British Journal of Social Psychology, 49, 69-89.

Reicher, S. D. (1984). The St. Pauls' riot: An explanation of the limits of crowd action in terms of a social identity model. European Journal of Social Psychology, 14, 1-21. DOI: $10.1002 /$ ejsp.2420140102

Reicher, S. D. (1996). 'The Battle of Westminster': Developing the social identity model of crowd behaviour in order to explain the initiation and development of collective conflict. European Journal of Social Psychology, 26, 115-134.

Reicher, S.D \& Hopkins, N. (2001) Self and Nation. London: Sage.

Roccas, S., Klar, Y. \& Liviatan, I. (2006). The paradox of group-based guilt: Modes of national identification, conflict vehemence, and reactions to the in-group's moral violations. Journal of Personality and Social Psychology, 91, 698-711.

Sani, F., \& Reicher, S.D. (2000). Contested identities and schisms in groups: opposing the ordination of women as priests in the Church of England. British Journal of Social Psychology, 39(1), 95-112.

Smith, L. G. E., \& Postmes, T. (2009). Intra-group interaction and the development of norms which promote inter-group hostility. European Journal of Social Psychology, 39(1), 130-144. DOI: $10.1002 /$ ejsp.464

Smith, L. G. E., \& Postmes, T. (2011a). Shaping stereotypical behaviour through the discussion of social stereotypes. British Journal of Social Psychology, 50(1), 74-98. DOI: $10.1348 / 014466610 \times 500340$ 
Smith, L. G. E., \& Postmes, T. (2011b). The power of talk: Developing discriminatory group norms through discussion. British Journal of Social Psychology, 50(2), 193-215. DOI: $10.1348 / 014466610 \times 504805$

Smith, L.G.E., Thomas, E.F. \& McGarty, C. (in press). "We must be the change we want to see in the world": Integrating norms and identities through social interaction. Political Psychology. DOI: 10.1111/pops.12180.

Stott, C., \& Drury, J. (2004). The importance of social structure and social interaction in stereotype consensus and content: Is the whole greater than the sum of its parts? European Journal of Social Psychology, 34(1), 11-23. DOI: 10.1002/ejsp.183

Stürmer, S., \& Simon, S. (2009). Pathways to collective protest: Calculation, identification or emotion? A critical analysis of the role of group-based anger in social movement participation. Journal of Social Issues, 65, 681-726.

Swaab, R., Postmes, T., van Beest, I., \& Spears, R. (2007). Shared cognition as a product of, and precursor to, shared identity in negotiations. Personality and Social Psychology Bulletin, 33, 187-199. DOI: 10.1177/0146167206294788

Tausch, N. \& Becker, J.C. (2013). Emotional reactions to success and failure of collective action as predictors of future action intentions: A longitudinal investigation in the context of student protests in Germany. British Journal of Social Psychology, 52, 525542.

Thomas, E.F., Mavor, K.I \& McGarty, C. (2012). Social identities can facilitate and encapsulate action relevant constructs. Group Processes and Intergroup Relations. 15(1), 75-88. DOI: $10.1177 / 1368430211413619$

Thomas, E. F., \& McGarty, C. A. (2009). The role of efficacy and moral outrage norms in creating the potential for international development activism through group-based 
interaction. British Journal of Social Psychology, 48, 115-134.

DOI: $10.1348 / 014466608 X 313774$

Thomas, E. F., McGarty, C., \& Louis, W. (2014). Social interaction and psychological pathways to political engagement and extremism. European Journal of Social Psychology, 44, 15-22. DOI: 10.1002/ejsp.1988

Thomas, E. F., McGarty, C., \& Mavor, K. I. (2009). Aligning identities, emotions and beliefs to create commitment to sustainable social and political action. Personality and Social Psychology Review, 13, 194-218. DOI: 10.1177/1088868309341563

Thomas, E.F., McGarty, C., Stuart, A., Lala., G., Hall, L. \& Goddard, A. (2015) Whatever happened to Kony2012? Studying a global online phenomenon as an emergent social identity. European Journal of Social Psychology, 45, 356-367.

Thomas, E. F., Smith, L. G. E., McGarty, C., \& Postmes, T. (2010). Nice and nasty: The formation of pro-social and hostile social movements. International Review of Social Psychology, 23(2/3), 17-55.

Turner, J. C. (1991). Social influence. Milton Keynes: Open University Press.

Turner, J. C., \& Oakes, P. J. (1986). The significance of the social identity concept for social psychology with reference to individualism, interactionism and social influence. British Journal of Social Psychology, 25, 237-252.

van Zomeren, M., Postmes, T., \& Spears, R. (2008). Toward an integrative social identity model of collective action: A quantitative research synthesis of three sociopsychological perspectives. Psychological Bulletin, 134, 504-535. DOI: $10.1037 / 0033-2909.134 .4 .504$ 
Wittenbaum, G.M. \& Moreland, R.L. (2008). Small-group research in social psychology: Topics and trends over time. Social and Personality Psychology Compass, 2/1, 187203. 
THE FOUNDATIONS OF IDENTITY AND ACTION

\section{Footnote}

${ }^{1}$ Some of these instructions also contained experimental manipulations designed to manipulate emotional or belief content of the discussions (as in Thomas \& McGarty, 2009) and / or the task focus of the group discussions. Some of these manipulations produced effects of small to moderate size and together they represent another source of variation. The effects reported here are robust in that they hold over and above these effects (for example, as routinely applies in a meta-analysis).

${ }^{2}$ We conducted exactly the same tests of EMSICA and SIMCA omitting the affect component from the latent identification factor. Results were unchanged though the SRMR within index was slightly worse (SRMR within $=.064$ for EMSICA, .060 for SIMCA), suggesting that it is worth retaining it in the models. 
Table 1.

Means (standard deviations) and cell sizes for measured variables

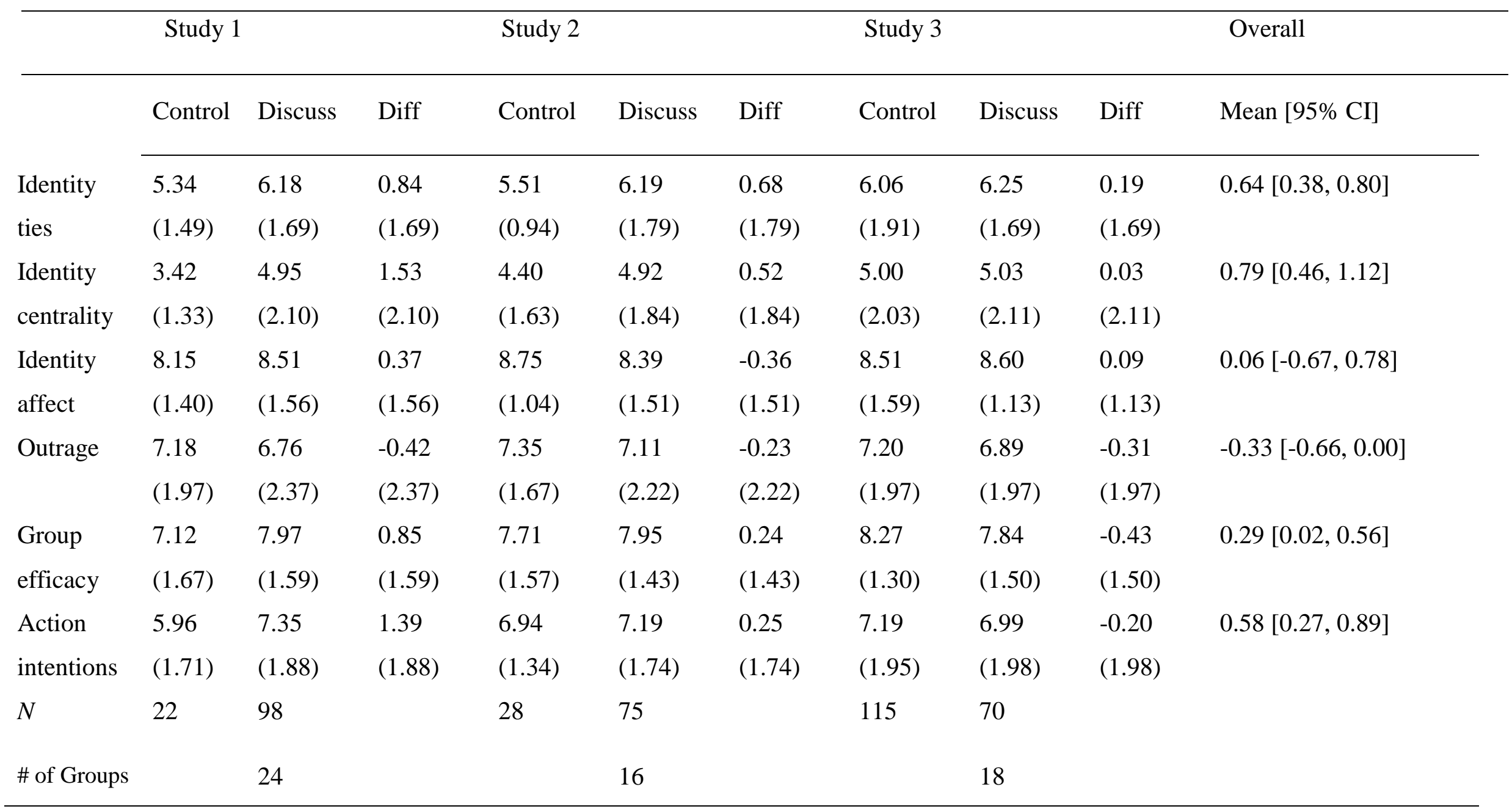


Table 2 .

Correlations between variables of interest

\begin{tabular}{lclllll}
\hline & $\begin{array}{l}\text { Social } \\
\text { identity }\end{array}$ & $\begin{array}{l}\text { Social } \\
\text { identity }\end{array}$ & $\begin{array}{l}\text { Social } \\
\text { identity }\end{array}$ & Outrage & Group & Action \\
& ties & centrality & affect & & & intention \\
& 1 & .48 & .42 & .32 & .54 & .62 \\
\hline Identity ties & & 1 & .29 & .19 & .44 & .61 \\
Identity centrality & & & 1 & .42 & .43 & .50 \\
Identity affect & & & & 1 & .36 & .46 \\
Outrage & & & & & 1 & .67 \\
Group efficacy & & & & & 1 \\
Action intentions & & & & & & \\
\hline
\end{tabular}

Note: As the results are from nonindependent data the conventional significance levels of the correlations have not been provided in this table but see Figures 1 and 2 for the results of multilevel modelling. 


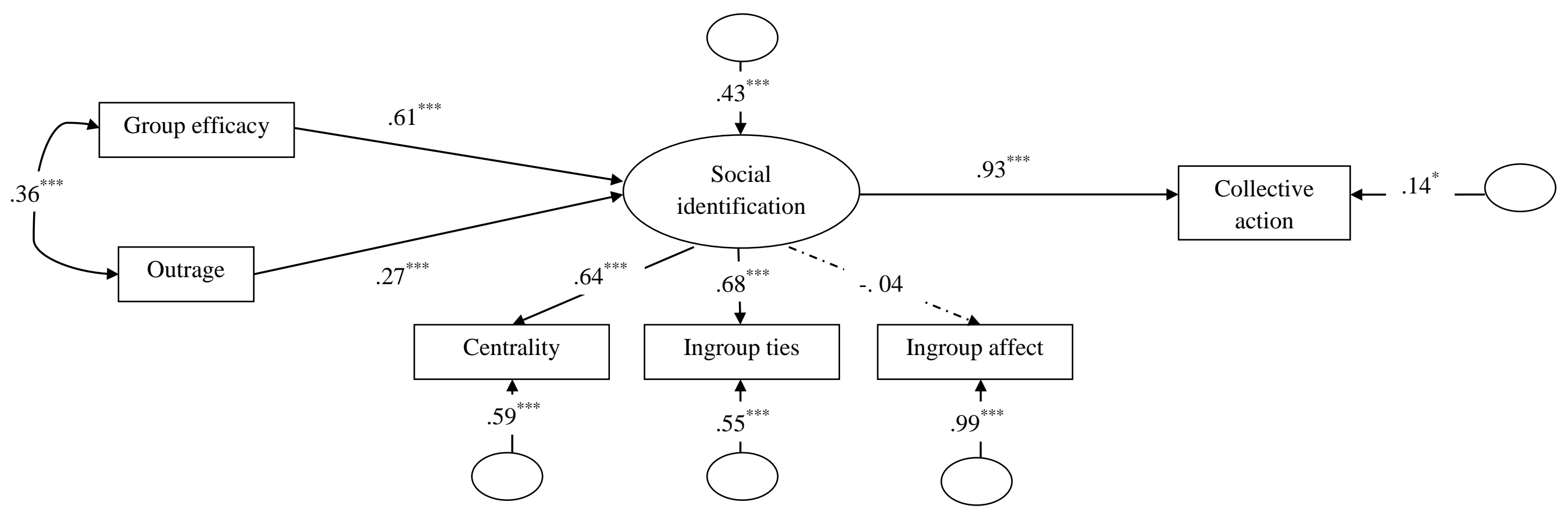

Figure 1. Standardized weights obtained for the encapsulated model of social identity in collective action (EMSICA). ${ }^{*}$ denotes $p<.05,{ }^{* * *}$ denotes $p<.001$. Dotted pathways represent those that are non-significant. SRMR (within) $=.06$. 
THE FOUNDATIONS OF IDENTITY AND ACTION 


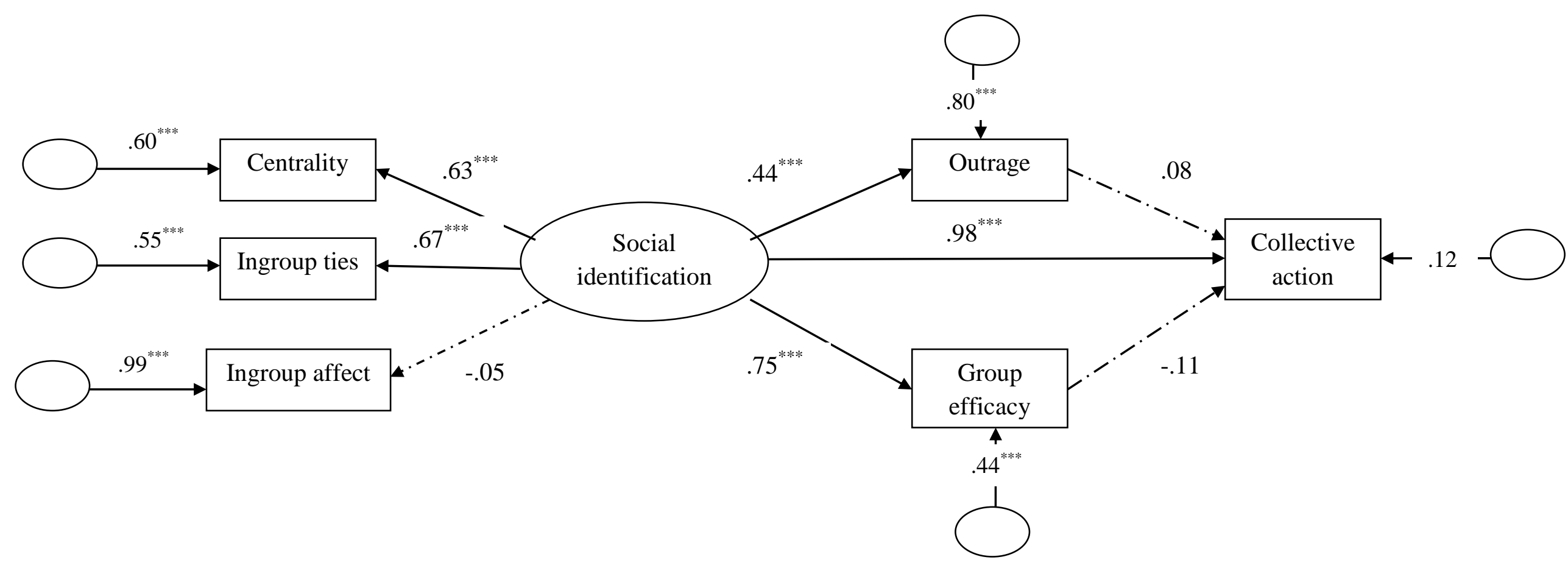

Figure 2. Standardized weights obtained for the social identity model of collective action (SIMCA) ${ }^{* * *}$ denotes $p<.001$. Dotted pathways represent those that are non-significant. SRMR (within) $=.057$. 